\title{
Prospects and Challenges of Adopting E-Commerce System in Pakistan - An Empirical Research
}

\author{
Syed Mubashir Ali \\ Institute of Business Management (loBM) \\ Korangi Creek, Karachi, Pakistan
}

\author{
Atif Ishaq \\ Shaheed Zulfiqar Ali Bhutto Institute of Science \& \\ Technology (SZABIST) \\ Academic City, Dubai, UAE
}

\begin{abstract}
The term e-commerce has evolved at a rapid pace throughout the world. Pakistan has only very recently witnessed the country wide e-commerce implementations. This paper discusses the opportunities and challenges of e-commerce implementation in Pakistani context. Literature review and empirical evidence has been used as research methodology. The findings revealed online shopping, e-banking and egovernment are some of the prospects of e-commerce implementation. Few challenges are also identified which includes social, cultural, privacy, legal and lack of education and awareness. This research can be used to successfully plan e-commerce implementations within Pakistan.
\end{abstract}

\section{General Terms}

e-commerce

\section{Keywords}

e-commerce, Pakistan, change management, technology management

\section{INTRODUCTION}

Ecommerce is basically a way of doing business especially involving transactions via the internet. The basic concept lies in the use of digital technology to carry out financial transactions online [1]. The use of the internet has been growing increasingly to that extent where the huge number of opportunities is being created in the field of ecommerce. Ecommerce business is having a large economical, social, political and cultural impact in the present world and in the future. It has been clearly notified that ecommerce has changed the face of the business. It has affected all the areas in many different ways. Main advancements are in the field of Information Technology \& other main economic sectors and it has increased the growth of productivity worldwide [2].

In this paper we will focus on the implications of E-commerce on society. By the social implications of ecommerce, we mean how the materialization of ecommerce has affected the society when 'online shopping' has become widely accepted and useful [3]. However with the innovation and expansion in the internet business, different characteristics of the social order and the public have created an immense effect and variation in the growth and acceptance of ecommerce in the society. It may have changed the customer perception by providing added value and providing them with the best services. It also addresses their concern about the security issues and to what extent the society considers it as ease of use [4]. There has been a considerable amount of research in this area and while some focus on the benefits of E-commerce, other researchers focus on the negative aspects of E-commerce on society. The presence of E-commerce helps in many ways one of which can be eradication of rural poverty by networking the rural poor to ensure their active participation in social activities [5]. However, it has been observed that E-commerce bears more costs then benefits for the poor and needy in developing countries like India [5]. Another issue observed is of security, since the goods are not handed over at the time of purchase and sometimes the shoppers have to enter their bank details for an online transaction. This causes feelings of fear and anxiety [1]. Research suggests that the extensive use of information technology and communication has created a Digital Divide (people who have access to and use ITCs and those who don't) [6].

The next section will discuss some of the current status and prospects of e-commerce in Pakistan. Section 3 will highlight some of the challenges and issues in e-commerce implementation and the last part will conclude the paper.

\section{PROSPECTS}

The movement from physical to virtual operation of business is growing at a very fast rate around the world. Every new or existing business is looking for ways in which it can mark a online presence. The concept of going out to carry out transactions is decreasing day by day with the help of ECommerce. The electronic operation of business gives the consumer the ease to view and order for goods and services online, everything from the purchase of cosmetics to booking a holiday is available online and is only a click away.

The rapid growth of E-Commerce is not confined to the developed countries. The developing countries are catching up fast in this race. They are continuously developing their technologies in order to avail the opportunities presented by E-commerce. The south Asian region displays the highest rate of growth in the dot com industry [7]. Pakistan has also witnessed drastic growth in internet penetration and usage with around 71 million broadband and 69 million 3G/4G subscribers [8].

\subsection{Online Shopping}

The use of the internet for the purpose of purchasing goods or services is called e-commerce or online shopping [9]. The arrival of social media websites such Facebook and Twitter has given a boost to the concept of online shopping this method of online sale of goods is called Social Commerce [10]. The concept of social commerce is very relevant for the Pakistani consumer as there is a great increase in the number of people adaption to social networking websites, Thus, providing the entrepreneurs a great opportunity to sell their goods online [11]. As a result, a number of e-commerce websites have emerged very recently in Pakistan such as daraz.pk, homeshopping.pk, mycart.pk offering electronics, clothes, grocery items etc. Also there has been an increasing trend in online food ordering service and "foodpanda" is very popular among these. Some other e-commerce sites such as dawaai.pk offering genuine medicines on prescription delivered to home. 


\subsection{E-banking}

The banking industry like the other industries is also making use of the cyberspace. Around $40 \%$ of the banking transactions today take place online [12]. It has been noted that in $199920 \%$ of the national banks in developing countries offered online banking services. The profits of banks offering online banking facilities have reported higher level of profit than the banks which do not offer online banking. Importantly the presence of E-readiness in developing countries like Pakistan indicates considerable opportunities.

The E-Banking system in Pakistan is progressing at a promising rate with 7000 banks (commercial) 90\% have branches in the urban areas and the National Institutional Facilitation Technologies (NIFT), reported that 14 cities in Pakistan make use of the automated cheque clearing system. The customer base of online services and ATMs is increasing as the young generation is keen on adapting to this new technology. However, there are certain barriers like age, education and infrastructure but if these issues are handled then there are great prospects of E-Banking in Pakistan [13].

\subsection{E-government}

E-Government is when the government of a country makes us of technologies such as the internet to transform their relations with the citizens [14]. The fast paced technological world of today leaves no room for laggards. The advancements keep coming up and it is our job or rather responsibility to keep up with the technological advancements. The implementation of e-government can make the system more effective and efficient as well as more transparent as this system makes the government more accessible and open for the citizens. Undoubtedly, E-government gives a vibe of a citizen centered government. However the implementation of such a system has many requirements such as access to government records and flawless internet facilities [15]

In Pakistan the use of e- government can be seen in the province of Khyber Pakhtunkhwa [16]. The government of KPK has developed a website for the ease of its citizens. The website offers many services for the citizens for example, location of schools, hospitals, and recreational sites. The government is working to including more services to their egovernment feature. Also very recently the Pakistan's government has launched an application named "Pakistan citizen portal" which citizens can use to directly give feedback or complain regarding government provided services to the Prime Minister for timely resolution of their problems [17].

\section{CHALLENGES}

Many of the human societies have welcomed this ecommerce phenomenon in the recent years and advancement in the late 20th century has brought us this amazing concept of ecommerce in to this world. The achievement of humanity in terms of ecommerce has just not changed itself but it also has a deep impact on the education, lifestyle, research methods, transportation, management, trade, health and security. In order to achieve the progress in society and economy we should eliminate the major challenges and should try to accept the reality of new technologies [18]. Therefore, let us examine the major challenges of ecommerce faced in our society.

\subsection{Lack of awareness and accessibility}

People say that ecommerce is creating more and more opportunities for growth in economy. But on the other hand it creates a digital gap (the differentiation between the people who have the knowledge and access of it and who don't have it) in the society as well [19]. And if we talk about Pakistan, here majority of the population is unqualified or uneducated. They are actually underprivileged when it comes to IT and ecommerce and that is a major concern. This is the main challenge; to make people aware of the ecommerce advancement in the technology.

\subsection{Lifestyle}

In Pakistan, the lifestyle is affected mainly in urban areas due to the wide use of ecommerce in those places. Especially, work-at-home and time \& flexibility combination have created an impact on families and their lives [20]. Now many of the people are not really spending what we call "quality time" with their families because of this advanced technology and they have to remain in contact with the business people all the time. They have online meetings, presentations and discussion with the people all around the world which actually is creating troubles into their families. Secondly majority of the people are identified to have issues in order to cope up with this information and communication advancement. Mainly they are people living in less developed regions or rural areas, old people, disabled people or women [21].

\subsection{Privacy}

The concept of privacy may have to be exchanged in such transactions, like health care quality maintenance or the access to the creditor but societal needs may also give the rise to the privacy concerns of the individuals particularly in public health case [22]. However, even knowing this information tradeoff, the consumers of ecommerce still want to control their personal information [23] In our society, very few ecommerce consumers think that they have the power over the use of their personal information which is being used in (online and offline) both the businesses. In this regard, the privacy threat has become a basic anger of the new users and it could easily decrease the number of online business and social firms [24].

\subsection{Social Isolation}

It has been observed that with the increase in the use of internet, people are spending more hours on the internet (for the office work or other) and lesser hours with their relatives, friends, on social gatherings and watching television [20]. Particularly this thing is creating the social isolation. People spend more time on internet leads to their less time with other human beings [25]. The other thing which is leading towards the social isolation in our society is where ecommerce is providing buying and selling from home. In this way the only time people are contacting with other people is when they sign their ordered-package or when they ask for any customer service, and because of that people are less informed about their neighborhood than in the earlier time [20].

\subsection{Cultural Issues}

In developing countries, shopping is considered as social activity and direct face-to-face contacts with sellers is an significant part of this whole shopping experience. Cultural obstacles in some countries may exist to discourage the approval of e-commerce as a mean of doing business [26]. In our society traditional shopping experience is more like a culture. People bargain and have fun with their families (especially on occasions) while shopping, so it's very difficult for people to shop online without having all these experiences. 


\subsection{Security and Legal Issues}

Due to the advancement in globalization and terrorism, there is a necessity to build a strong security system in respect of ecommerce. A company is at risk if it does not built a security system which ultimately leads to customer and profit loss. Because of these possibilities of risks, there is a need to establish security technology in order to progress in ecommerce business. Components like firewall, LAN security, and internet should be authentic and certain to ensure the reliability of the system [27]. In order to cope up with this issue, laws and regulations are made that describe the conduct of business internationally and locally. But even these laws are not effectively preventing malicious users and hackers from illegal actions and this really disturb the ecommerce users.

\subsection{Loss of Individuality}

It In today's world, we can observe that the business is heading towards providing the customers more value so there is a need to establish strong customer data base. In this regard the companies need all the personal information about their customers. People are having this problem to have no control over their personal information which the businesses get about them and even there is no restriction to collect such information in order to build a company's database [20].So people are having this fear to loss individuality if it continues to disturb their personal space and ultimately they would have no control over their personal information anymore [28]..

\section{CONCLUSION}

Electronic commerce has changed the way people and society used to trade, communicate and collaborate with each other and organizations. But every technology implementation brings having its own benefits give rise to some challenges too which needs to be catered in order to successfully implement and ripe the benefits of the technology [29], [30]. This study discusses the current advancements in e-commerce implementations and prospects along with identifying some challenges in Pakistani context. Future research can be done to investigate the penetration of electronic commerce in Pakistan and if the society, people and organizations have managed to ripe its benefits using surveys and case studies.

\section{REFERENCES}

[1] Z. M. El Gawady. 2005. The impact of e-commerce on developed and developing countries case study: Egypt and united states. International conference of Globalization, Technology and Sustainable Development, United Arab Emirates University, World Association for sustainable Development, Al Ain, UAE.

[2] J. E. Lawrence and U. A. Tar. 2010. Barriers to ecommerce in developing countries. Information, society and justice journal, vol. 3, no. 1, pp. 23-35.

[3] J. E. Lawrence. 2011. The growth of e-commerce in developing countries: an exploratory study of opportunities and challenges for SMEs. International Journal of ICT Research and Development in Africa (IJICTRDA), vol. 2, no. 1, pp. 15-28.

[4] P. D. Ojukwu. 2016. Redressing the Lack of Trust within SMEs Engaging in E-Commerce Activities in Developing Countries: A Nigerian Case Study. The International Journal of Science and Technoledge, vol. 4, no. 1, p. 51.
[5] S. Singh. 2009. Social implications of electronic commerce'. Journal of Social Science, vol. 21, no. 2, pp. 91-97.

[6] S. Sharma and R. Pratap. 2013. A Case Study of Risks optimization Using AHP Method. International Journal of Scientific and Research Publications, p. 579.

[7] P. Dasgupta and K. Sengupta. 2002. E-commerce in the Indian insurance industry: prospects and future. Electronic Commerce Research, vol. 2, no. 1-2, pp. 4360.

[8] Telecom Indicators PTA. [Online]. Available: https://www.pta.gov.pk/en/telecom-indicators. [Accessed: 23-Jul-2019].

[9] F. Mazhar, F. A. Jam, and F. Anwar. 2012. Consumer trust in e-commerce: A study of consumer perceptions in Pakistan. African Journal of Business Management, vol. 6, no. 7, pp. 2516-2528.

[10] L. Harris and A. Rae. 2009. Social networks: the future of marketing for small business. Journal of business strategy, vol. 30, no. 5, pp. 24-31.

[11] A. Talat, S. Azar, and M. W. Yousaf. 2013. Investigating social commerce as an alternate model for online commerce in developing countries: A case of Pakistani economy. Pakistan Journal of Commerce and Social Sciences (PJCSS), vol. 7, no. 1, pp. 223-242.

[12] K. Furst, W. W. Lang, and D. E. Nolle. 2000. Internet banking: developments and prospects. Office of the Comptroller of the Currency Economic and Policy Analysis Working Paper, no. 2000-9.

[13] A. G. Waince. 2013. Opportunities and constraints in expending e-banking in developing countries. Interdisciplinary Journal of Contemporary Research in Business, vol. 4, no. 11, p. 15.

[14] S. C. J. Palvia and S. S. Sharma. 2007. E-government and e-governance: definitions/domain framework and status around the world. International Conference on Egovernance, pp. 1-12.

[15] M. H. Hassan and J. Lee. 2019. Policymakers' perspective about e-Government success using AHP approach: Policy implications towards entrenching Good Governance in Pakistan. Transforming Government: People, Process and Policy, vol. 13, no. 1, pp. 93-118.

[16] Khyber Pakhtunkhwa Official Web Portal. [Online]. Available: $\quad \mathrm{http}: / / \mathrm{kp} . g o v . p k / G o v / G o v e r n m e n t . p h p$. [Accessed: 23-Jul-2019].

[17] Pakistan Citizen Portal - Apps on Google Play. [Online]. Available: https://play.google.com/store/apps/details?id=com.govpk .citizensportal\&hl=en. [Accessed: 23-Jul-2019].

[18] S. Gilaninia and M. Rahemi. 2012. Survey of Effective Factors on Customers Trends in Uses of POS Services in Electronic Banking. Journal of Basic and Applied Scientific Research, vol. 2, no. 4, pp. 3557-3562.

[19] T. Garín-Muñoz, R. López, T. Pérez-Amaral, I. Herguera, and A. Valarezo. 2019. Models for individual adoption of eCommerce, eBanking and eGovernment in Spain. Telecommunications Policy, vol. 43, no. 1, pp. 100-111. 
[20] S. K. Sharma. 2005. Socio-economic impacts and influences of e-commerce in a digital economy. Digital economy: Impacts, influences and challenges, IGI Global, pp. 1-20.

[21] N. Butt, N. F. Warraich, and M. Tahira. 2019. Development level of electronic government services: An empirical study of e-government websites in Pakistan. Global knowledge, memory and communication, vol. 68 , no. $1 / 2$, pp. 33-46.

[22] A. Baskaran, A. Sriram, S. Bonthala, and J. V. Vatti. 2019. Smart HealthCare System Using IoT with ECommerce. International Conference on Computer Networks and Communication Technologies, pp. 361369.

[23] A. Srivastava. 2006. Electronic signatures: a brief review of the literature. Proceedings of the 8 th international conference on Electronic commerce: The new ecommerce: innovations for conquering current barriers, obstacles and limitations to conducting successful business on the internet, pp. 605-609.

[24] R. Liu. 2015. The Influence of Privacy Awareness and Privacy Self-efficacy in E-commerce. PhD Thesis. University of North Carolina at Greensboro.
[25] R. Nowland, E. A. Necka, and J. T. Cacioppo. 2018. Loneliness and social internet use: pathways to reconnection in a digital world?. Perspectives on Psychological Science, vol. 13, no. 1, pp. 70-87.

[26] H. U. Khan and S. Uwemi. 2018. What are e-commerce possible challenges in developing countries: a case study of Nigeria. International Journal of Business and Systems Research, vol. 12, no. 4, pp. 454-486.

[27] M. Schaub. 2004. European legal aspects of ecommerce. Europa Law Publishing.

[28] B. J. Corbitt, T. Thanasankit, and H. Yi. 2003. Trust and e-commerce: a study of consumer perceptions. Electronic commerce research and applications, vol. 2, no. 3, pp. 203-215.

[29] S. M. Ali. 2013. Challenges and Benefits of Implementing Tablets in Classroom for e-Learning in a K-12 Education Environment-Case Study of a School in United Arab Emirates. Research Inventy: International Journal of Engineering and Science, vol. 3, no. 4.

[30] S. M. Ali, T. A. Jilani, A. Kidwai, H. Noor, and R. Shah. 2015. University Students' Perception on the Impact of 3G Mobile Broadband in Pakistan-A Survey. Research Inventy: International journal of Engineering and Science, vol. 5, no. 2. 